\title{
Cobalamin and Folate Deficiencies among Children in the Age Group of 12-59 Months in India
}

\author{
Umesh Kapil ${ }^{1}$, G. S. Toteja ${ }^{2}$, Ajeet Singh Bhadoria ${ }^{3}$
}

Background: Anemia is a major public health problem among children under 5 years of age in India. Cobalamin and folate deficiencies play an important role in the etiology of anemia. This study was done to assess the prevalence of cobalamin and folate deficiencies among children in the age group of 12-59 months.

Methods: A community-based cross-sectional study was conducted. A total of 470 children were included. Non-fasting venous blood samples were collected from each child for the estimation of serum cobalamin and folate levels. Pattern of dietary consumption of the each child was assessed with the help of the food frequency questionnaire (FFQ) method.

Results: The median levels (interquartile range) of serum cobalamin $(n=469)$ and folate $(n=416)$ were found to be 275 (202-427) pg/ml and 3.02 (2.02-4.94) ng/ml, respectively. The overall prevalence of cobalamin and folate deficiencies was found to be $180 / 469$ [38.4\%; 95\% Confidence Interval (CI): 34.1-42.8\%] and 263/416 (63.2\%; 95\% CI: 58.5-67.7\%), respectively.

Conclusions: A high prevalence of cobalamin and folate deficiencies was found in children under 5 years of age.

(Biomed J 2015;38:162-166)

Key words: anemia, folic acid deficiency, vitamin $B_{12}$ deficiency

\section{At a Glance Commentary \\ Scientific background of the subject}

Anemia and micronutrient deficiencies among children continue to be major public health challenges in most developing countries. There is lack of data on the status of cobalamin and folate deficiencies among children in the age group of 12-59 months in India. There are also only a few studies available in the international scenario.

\section{What this study adds to the field}

This study adds to the existing knowledge. It provides lead to the scientists working in the field of etiology of anemia that cobalamin and folate deficiencies may be linked to anemia. This study contributes to our understanding that cobalamin and folate deficiencies may also be responsible in the causation of anemia. It suggests policy makers and stakeholders to consider the addition of cobalamin along with folic acid to the iron tablets which are being distributed for combating anemia in the communities.

\section{METHODS}

Drevalence of anemia among young children continues 1 to remain over $70 \%$ in India. This makes it a major public health problem in the country. The National Family Health Survey (NFHS-3) conducted in the year 2005-2006 provided scientific evidence for high prevalence of anemia in all states of the country. ${ }^{[1]}$ Apart from the deficiency of iron, cobalamin and folate deficiencies play an important role in the etiology of anemia among young children. There is limited scientific data available in India on the prevalence of cobalamin and folate deficiencies among children under 5 years of age. Hence, this study was conducted to provide scientific evidence in this area.
A community-based cross-sectional study was conducted. Four hundred seventy children residing in a population catered by Integrated Child Development Scheme (ICDS) in the National Capital Territory (NCT) of Delhi were enrolled by purposive sampling. Data on socio-demographic profile, educational status of mothers (of children), family type, standard of living (SLI), and religion and caste of the children were collected through a pretested structured questionnaire. The criterion for classifying the families into different socioeconomic groups was based on the physical assets available in

From the ${ }^{1}$ Department of Human Nutrition, All India Institute of Medical Sciences, Ansari Nagar, New Delhi, India; ${ }^{2}$ Indian Council of Medical Research, Ansari Nagar, New Delhi, India; ${ }^{3}$ Department of Epidemiology, Institute of Liver and Biliary Sciences, New Delhi, India Received: Jun. 05, 2013; Accepted: Jun. 20, 2014

Correspondence to: Dr. Umesh Kapil, Department of Human Nutrition, All India Institute of Medical Sciences, Ansari Nagar, New Delhi, India. New Delhi - 110029, India. Tel: 91-11-26593383; Fax: 91-11-26588663; E-mail: umeshkapil@gmail.com

DOI: $10.4103 / 2319-4170.137768$ 
the household. This had been earlier utilized by the NFHSs in India. ${ }^{[1]}$ Current morbidity status of each child was assessed by diagnosing the morbid conditions such as diarrhea, fever, respiratory infection, ring worm, measles, mouth ulcer, dysentery, upper respiratory tract infection (URTI), etc. during the last $24 \mathrm{~h}$ at the time of the interview. The children suffering from any morbidity at the time of survey were excluded.

Pattern of dietary consumption of the each child was assessed with the help of the food frequency questionnaire (FFQ) method. This method obtains retrospective information on the pattern of consumption of the food items categorized into major food groups like cereals/grains (wheat and rice), pulses and legumes, green leafy vegetables, roots and tubers, other vegetables, fruits, milk, milk products, eggs, flesh foods, nuts and oil seeds, fats and oils, and sugar/jaggery at a defined period in the past. The common food items consumed by the children were listed so that the mothers could be facilitated to comprehend and recall the food items consumed by their children. The mother of the child was enquired about the frequency of intake of the food items of specific food groups during the last 6 months of the survey. The frequency of consumption was assessed under four categories: (1) Number of days per week (1-7 days), (2) once per 15 days, (3) once per month, and (4) never.

\section{Collection of blood sample}

Non-fasting venous blood samples were collected from each child for the estimation of serum cobalamin and folate levels. The blood samples were collected from 8 a.m. to 12 noon and transported to the field laboratory. Samples were centrifuged at $2500-3000 \mathrm{rpm}$ for 10-15 min to separate serum. The serum samples were then transported to the Central Laboratory and stored at $-70^{\circ} \mathrm{C}$.

The serum C-reactive protein (CRP) level was estimated in each sample using high-sensitivity CRP enzyme-linked immunosorbent assay (ELISA). The blood samples with $\mathrm{CR} P$ values $8.2 \mathrm{mg} / \mathrm{l}$ and above were excluded for the estimation of serum cobalamin and folate.

\section{Criteria for cobalamin and folate deficiencies}

According the World Health Organization (WHO), serum cobalamin level of less than $203 \mathrm{pg} / \mathrm{ml}$ and serum folate level of less than $4 \mathrm{ng} / \mathrm{ml}$ are the cut-offs in children that show deficiency: ${ }^{[2]}$

The data were statistically analyzed using SPSS-22.0 (International Business Machine (IBM) Statistical Package for Social Sciences Statistics Version 22.0, Institute of Liver and Biliary Sciences, New Delhi). The variables were categorized into two to four groups depending on the variable and its response. After categorization of data, the descriptive statistics (frequency distribution and percentages) were calculated. The estimation of cobalamin and folate levels in serum was carried out in the National Accreditation Board for Testing and Calibration Laboratories (NABL) accredited laboratory, "Centre for Promotion of Nutrition Research and Training with special reference to North-East, Tribal and Inaccessible Population" of Indian Council of Medical Research (ICMR), New Delhi. Standard laboratory methods were used for the estimation of serum cobalamin and folate levels. Serum folate was determined by the radioimmunoassay (RIA) method and serum cobalamin by the radioisotopic method..$^{[-5]}$ The study was ethically approved by the ethics committee of the All India Institute of Medical Sciences, New Delhi. Written informed consent was obtained from either of the parents of each child. Details of the study were given in writing and also read out aloud in front of parents (in case of illiterates) in the presence of a witness. The children of those parents who gave consent for their participation were enrolled in the study.

\section{RESULTS}

A total of 470 children were included in the study. The proportion of male and female children was almost equal. Estimation of cobalamin and folate was done in the serum samples of 469 and 416 children, respectively. The median levels (interquartile range) of serum cobalamin and folate were found to be $275(202-427) \mathrm{pg} / \mathrm{ml}$ and 3.02 (2.024.94) $\mathrm{ng} / \mathrm{ml}$, respectively. The median folate levels were insignificantly low among the cobalamin-deficient children. However, the median cobalamin levels were found to be insignificantly high among the folate-deficient children $(p>0.05)$ [Table 1].

In the present study, cobalamin deficiency was found in $180 / 416(38.38 \%)$ children $(36.8 \%$ among boys and $40 \%$ among girls) [Table 2]. The subjects belonging to low

Table 1: Serum cobalamin $(n=469)$ and folate $(n=416)$ levels (median with interquartile range) among children aged $12-59$ months

\begin{tabular}{|c|c|c|c|c|c|c|}
\hline Serum levels & Deficient in cobalamin & Not deficient in cobalamin & $p$ value* & Deficient in folate & Not deficient in folate & $p$ value* \\
\hline \multicolumn{7}{|l|}{ Cobalamin levels (pg/ml) } \\
\hline$n$ & & & & 263 & 153 & \\
\hline Median (interquartile range) & & & & $247(176-386)$ & $242(164-397)$ & 0.58 \\
\hline \multicolumn{7}{|l|}{ Folate levels (ng/ml) } \\
\hline$n$ & 180 & 289 & & & & \\
\hline Median (interquartile range) & $2.99(1.92-4.69)$ & $3.02(2.04-5.14)$ & 0.47 & & & \\
\hline
\end{tabular}


SLI $(43.7 \%)$ were more deficient when compared to those belonging to medium SLI (37.6\%) and high SLI (18.6\%) $(p<0.001)$. A high deficiency of cobalamin was found among children belonging to Schedule Caste (SC) (50\%) and Other Backward Caste (OBC) (48.6\%) as compared to those of Schedule Tribe (ST) (39.7\%) and other castes $(15.8 \%)(p<0.001)$. Cobalamin deficiency was significantly lower in children who consumed flesh foods and eggs more frequently $(p<0.05)$. Cobalamin deficiency was more prevalent in vegetarian subjects $(50.4 \%)$ in comparison to non-vegetarian subjects $(33.8 \%)(p=0.001)$. On multiple logistic regression analysis, it was found that children belonging to low SLI, SC, ST, and OBC, and not consuming flesh in diet were more deficient [Table 3].

In the present study, folate deficiency was found in 263/416 (63.22\%) children. It was equally prevalent among boys $(65.4 \%)$ and girls $(60.9 \%)$ [Table 4 ]. The subjects belonging to high SLI (75.4\%) were more folate deficient when compared to those belonging to medium SLI (62.4\%) and low SLI $(60.6 \%)(p=0.11)$. About $50 \%$ of SC subjects were folate deficient. Folate deficiency was less amongst children consuming foods regularly with low sugar, more eggs, less fats and oils, less milk and milk products, and fewer nuts. Folate deficiency was more prevalent in vegetarian (74.3\%) subjects as compared to non-vegetarian $(59.1 \%)$ subjects $(p=0.004)$. On multiple logistic regression analysis, it was found that children on vegetarian diet with high consumption of milk, fats, and oils were more deficient [Table 5].

\section{DISCUSSION}

The present study was conducted to assess the prevalence of cobalamin and folate deficiencies amongst children in the age group of 12-59 months. The overall prevalence of cobalamin deficiency was found to be $38.38 \%$ (95\% CI: $34.1-42.8 \%)$. Two previous studies from India have reported lower prevalence of cobalamin deficiency ( $9 \%$ and $14.4 \%$, respectively) as compared with the results of present study. ${ }^{[6,7]}$ However, higher prevalence of cobalamin deficiency of $50 \%$ has been reported in another earlier study. ${ }^{[8]}$

The prevalence of folate deficiency was found to be 63.22\% (95\% CI: 58.5-67.7\%). An earlier study conducted amongst children of similar age group documented a folate deficiency of $33 \% .{ }^{[6]}$ This variation could be due to the different cut-offs utilized for classification of children with folate deficiency. Earlier studies have also documented a prevalence of $62 \%$ and $65 \% .{ }^{[7,8]}$

In the present study, $13.5 \%$ children had concomitant prevalence of cyanocobalamin and folate deficiencies. This finding indicates that cobalamin and folate deficiencies could be independent etiological factors in the causation of nutritional anemia amongst young children.
The present study was undertaken in children who consumed a cereal-based diet which provides about $90 \%$ of the calories. The cobalamin and folate deficiencies in

Table 2: Characteristics of cyanocobalamin deficiency amongst children aged 12-59 months $(n=469)$

\begin{tabular}{|c|c|c|c|c|}
\hline Characteristics & $\begin{array}{c}\text { Non-deficient } \\
(n=289)\end{array}$ & $\begin{array}{c}\text { Deficient } \\
(n=180)\end{array}$ & $\begin{array}{c}\text { Total } \\
(n=469)\end{array}$ & $p$ value* \\
\hline \multicolumn{5}{|l|}{ Gender } \\
\hline Male & $151(63.2)$ & $88(36.8)$ & $239(51.0)$ & \multirow[t]{2}{*}{0.507} \\
\hline Female & $138(60.0)$ & $92(40.0)$ & $230(49.0)$ & \\
\hline \multicolumn{5}{|l|}{ Caste } \\
\hline Schedule tribe & $76(60.3)$ & $50(39.7)$ & $126(26.9)$ & \multirow[t]{4}{*}{$<0.001$} \\
\hline Schedule caste & $28(50.0)$ & $28(50.0)$ & $56(11.9)$ & \\
\hline Other backward caste & $89(51.4)$ & $84(48.6)$ & $173(36.9)$ & \\
\hline Others & $96(84.2)$ & $18(15.8)$ & $114(24.3)$ & \\
\hline \multicolumn{5}{|l|}{ Religion } \\
\hline Hindu & $244(58.5)$ & $173(41.5)$ & 417 (88.9) & \multirow[t]{3}{*}{$<0.001$} \\
\hline Muslim & $40(85.1)$ & $7(14.9)$ & $47(10.0)$ & \\
\hline Others & $5(100.0)$ & $0(0.0)$ & $5(1.1)$ & \\
\hline \multicolumn{5}{|l|}{ Standard of living (SLI) } \\
\hline Lower & $138(56.3)$ & $107(43.7)$ & $245(52.2)$ & \multirow[t]{3}{*}{0.002} \\
\hline Middle & $103(62.4)$ & $62(37.6)$ & $165(35.2)$ & \\
\hline High & $48(81.4)$ & $11(18.6)$ & $59(12.6)$ & \\
\hline \multicolumn{5}{|l|}{ Dietary habits } \\
\hline Vegetarian & $64(49.6)$ & $65(50.4)$ & $129(27.5)$ & \multirow[t]{2}{*}{0.001} \\
\hline Non-vegetarian & $225(66.2)$ & $115(33.8)$ & $340(72.5)$ & \\
\hline \multicolumn{5}{|l|}{ Consumption of flesh } \\
\hline 7 days a week & $9(100.0)$ & $0(0.0)$ & $9(1.9)$ & \multirow[t]{3}{*}{0.001} \\
\hline 1-6 days a week & $155(69.2)$ & $69(30.8)$ & $224(47.8)$ & \\
\hline Never & $125(53.0)$ & $111(47.0)$ & $236(50.3)$ & \\
\hline \multicolumn{5}{|l|}{ Consumption of milk } \\
\hline 7 days a week & $176(60.9)$ & $113(39.1)$ & $289(61.6)$ & \multirow[t]{3}{*}{0.899} \\
\hline 1-6 days a week & $42(61.8)$ & $26(38.2)$ & $68(14.5)$ & \\
\hline Never & $71(63.4)$ & $41(36.6)$ & $112(23.9)$ & \\
\hline \multicolumn{5}{|l|}{$\begin{array}{l}\text { Consumption of milk } \\
\text { products }\end{array}$} \\
\hline 7 days a week & $55(54.5)$ & $46(45.5)$ & $101(21.5)$ & \multirow[t]{3}{*}{0.084} \\
\hline 1-6 days a week & $146(66.7)$ & $73(33.3)$ & $219(46.7)$ & \\
\hline Never & $88(59.1)$ & $61(40.9)$ & $149(31.8)$ & \\
\hline \multicolumn{5}{|l|}{$\begin{array}{l}\text { Consumption of fats } \\
\text { and oils }\end{array}$} \\
\hline 7 days a week & $120(64.9)$ & $65(35.1)$ & $185(39.4)$ & \multirow[t]{3}{*}{0.124} \\
\hline 1-6 days a week & $127(62.6)$ & $76(37.4)$ & $203(43.3)$ & \\
\hline Never & $42(51.9)$ & $39(48.1)$ & $81(17.3)$ & \\
\hline \multicolumn{5}{|l|}{ Consumption of nuts } \\
\hline 7 days a week & $23(74.2)$ & $8(25.8)$ & $31(6.6)$ & \multirow[t]{3}{*}{0.148} \\
\hline 1-6 days a week & $160(63.2)$ & $93(36.8)$ & $253(53.9)$ & \\
\hline Never & $106(57.3)$ & $79(42.7)$ & $185(39.4)$ & \\
\hline \multicolumn{5}{|l|}{ Consumption of eggs } \\
\hline 7 days a week & $20(87.0)$ & $3(13.0)$ & $23(4.9)$ & \multirow[t]{3}{*}{0.006} \\
\hline 1-6 days a week & $143(64.7)$ & $78(35.3)$ & $221(47.1)$ & \\
\hline Never & $126(56.0)$ & $99(44.0)$ & $225(48.0)$ & \\
\hline \multicolumn{5}{|l|}{ Consumption of sugar } \\
\hline 7 days a week & $226(62.1)$ & $138(37.9)$ & $364(77.6)$ & 0.901 \\
\hline 1-6 days a week & $33(61.1)$ & $21(38.9)$ & $54(11.5)$ & \\
\hline
\end{tabular}
Contd... 
Table 2: Contd...

\begin{tabular}{lcccc}
\hline Characteristics & $\begin{array}{c}\text { Non-deficient } \\
(n=289)\end{array}$ & $\begin{array}{c}\text { Deficient } \\
(n=180)\end{array}$ & $\begin{array}{c}\text { Total } \\
(n=469)\end{array}$ & $p$ value* \\
\hline Never & $30(58.8)$ & $21(41.2)$ & $51(10.9)$ & \\
$\begin{array}{l}\text { Consumption of green } \\
\text { leafy vegetables }\end{array}$ & & & & \\
7 days a week & $62(61.4)$ & $39(38.6)$ & $101(21.5)$ & 0.684 \\
$1-6$ days a week & $181(62.8)$ & $107(37.2)$ & $288(61.4)$ & \\
Never & $46(57.5)$ & $34(42.5)$ & $80(17.1)$ &
\end{tabular}

*Chi-square test, figures in parenthesis are percentages

Table 3: Independent risk factors for cobalamin deficiency as per forward conditional multiple logistic regression analysis

\begin{tabular}{|c|c|c|c|}
\hline Parameters & $\beta$-coefficient & Odds ratio $(95 \% \mathrm{CI})$ & $p$ value \\
\hline \multicolumn{4}{|l|}{ Consumption of flesh } \\
\hline Never & & Reference category & \\
\hline $1-6$ or 7 days a week & 0.493 & $1.637(1.091-2.455)$ & 0.017 \\
\hline \multicolumn{4}{|l|}{ Caste } \\
\hline Others (general caste) & & Reference category & \\
\hline Schedule tribe & 0.957 & $2.605(1.360-4.989)$ & 0.004 \\
\hline Schedule caste & 1.331 & $3.784(1.760-8.135)$ & 0.001 \\
\hline Other backward caste & 1.363 & $3.908(2.126-7.184)$ & $<0.001$ \\
\hline \multicolumn{4}{|l|}{ Standard of living (SLI) } \\
\hline High SLI & & Reference category & \\
\hline Middle SLI & 0.736 & $2.087(0.973-4.475)$ & 0.059 \\
\hline Low SLI & 0.942 & $2.564(1.202-5.470)$ & 0.015 \\
\hline
\end{tabular}

Abbreviation: CI: Confidence interval

Table 4: Characteristics of folate deficiency amongst children aged 12-59 months $(n=416)$

\begin{tabular}{|c|c|c|c|c|}
\hline Characteristics & $\begin{array}{c}\text { Non-deficient } \\
\quad(n=153)\end{array}$ & $\begin{array}{l}\text { Deficient } \\
(n=263)\end{array}$ & $\begin{array}{c}\text { Total } \\
(n=416)\end{array}$ & $p$ value* \\
\hline \multicolumn{5}{|l|}{ Gender } \\
\hline Male & $74(34.6)$ & $140(65.4)$ & 214 & \multirow[t]{2}{*}{0.338} \\
\hline Female & $79(39.1)$ & $123(60.9)$ & $202(48.6)$ & \\
\hline \multicolumn{5}{|l|}{ Caste } \\
\hline Schedule tribe & $43(37.7)$ & $71(62.3)$ & $114(27.4)$ & \multirow[t]{4}{*}{0.023} \\
\hline Schedule caste & $26(50.0)$ & $26(50.0)$ & $52(12.5)$ & \\
\hline Other backward caste & $58(38.9)$ & $91(61.1)$ & $149(35.8)$ & \\
\hline Others & $26(25.7)$ & $75(74.3)$ & $101(24.3)$ & \\
\hline \multicolumn{5}{|l|}{ Religion } \\
\hline Hindu & $142(38.4)$ & $228(61.6)$ & 370 & \multirow[t]{3}{*}{0.080} \\
\hline Muslim & $11(26.8)$ & $30(73.2)$ & $41(9.9)$ & \\
\hline Others & $0(0.0)$ & $5(100.0)$ & $5(1.2)$ & \\
\hline \multicolumn{5}{|l|}{ Standard of living (SLI) } \\
\hline Lower SLI & $86(39.4)$ & $132(60.6)$ & $218(52.4)$ & \multirow[t]{3}{*}{0.113} \\
\hline Middle SLI & $53(37.6)$ & $88(62.4)$ & $141(33.9)$ & \\
\hline High SLI & $14(24.6)$ & $43(75.4)$ & $57(13.7)$ & \\
\hline \multicolumn{5}{|l|}{ Dietary habits } \\
\hline Vegetarian & $29(25.7)$ & $84(74.3)$ & $113(27.2)$ & \multirow[t]{2}{*}{0.004} \\
\hline Non-vegetarian & $124(40.9)$ & $179(59.1)$ & $303(72.8)$ & \\
\hline \multicolumn{5}{|l|}{ Consumption of flesh } \\
\hline 7 days a week & $1(11.1)$ & $8(88.9)$ & $9(2.2)$ & \multirow[t]{2}{*}{0.271} \\
\hline 1-6 days a week & $74(37.6)$ & $123(62.4)$ & $197(47.4)$ & \\
\hline Never & $78(37.1)$ & $132(62.9)$ & $210(50.5)$ & \\
\hline
\end{tabular}

Table 4: Contd...

\begin{tabular}{lcccc}
\hline Characteristics & $\begin{array}{c}\text { Non-deficient } \\
(n=153)\end{array}$ & $\begin{array}{c}\text { Deficient } \\
(n=263)\end{array}$ & $\begin{array}{c}\text { Total } \\
(n=416)\end{array}$ & $p$ value* \\
\hline $\begin{array}{l}\text { Consumption of milk } \\
7 \text { days a week }\end{array}$ & $84(33.9)$ & $164(66.1)$ & $248(59.6)$ & 0.029 \\
1-6 days a week & $20(30.8)$ & $45(69.2)$ & $65(15.6)$ & \\
Never & $49(47.6)$ & $54(52.4)$ & $103(24.8)$ & \\
Consumption of milk & & & & \\
products & & & & \\
7 days a week & $26(29.9)$ & $61(70.1)$ & $87(20.9)$ & 0.005 \\
1-6 days a week & $65(32.5)$ & $135(67.5)$ & $200(48.1)$ & \\
Never & $62(48.1)$ & $67(51.9)$ & $129(31.0)$ & \\
Consumption of fats & & & & \\
and oils & & & & \\
7 days a week & $35(22.0)$ & $124(78.0)$ & $159(38.2$ & $<0.001$ \\
1-6 days a week & $71(38.2)$ & $115(61.8)$ & $186(44.7)$ & \\
Never & $47(66.2)$ & $24(33.8)$ & $71(17.1)$ & \\
Consumption of nuts & & & & \\
7 days a week & $11(37.9)$ & $18(62.1)$ & $29(7.0)$ & 0.001 \\
1-6 days a week & $66(29.2)$ & $160(70.8)$ & $226(54.3)$ & \\
& & & & \\
7 days a week & $36(41.4)$ & $51(58.6)$ & $87(20.9)$ & $<0.001$ \\
1-6 days a week & $77(29.7)$ & $182(70.3)$ & $259(62.3)$ & \\
Never & $40(57.1)$ & $30(42.9)$ & $70(16.8)$ & \\
\hline
\end{tabular}

*Chi-square test, figures in parenthesis are percentages

Table 5: Independent risk factors for folate deficiency as per forward conditional multiple logistic regression analysis

\begin{tabular}{lccc}
\hline Parameters & $\beta$-coefficient & Odds ratio (95\% CI) & $p$ value \\
\hline $\begin{array}{l}\text { Dietary habits } \\
\quad \text { Non-vegetarian }\end{array}$ & & Reference category \\
$\quad$ Vegetarian & 0.736 & $2.15(1.27-3.62)$ & 0.004 \\
Consumption of milk & & Reference category \\
$\quad$ Never & 0.865 & $2.38(1.16-4.89)$ & 0.019 \\
1-6 days a week & 0.520 & $1.68(1.01-2.83)$ & 0.049 \\
7 days a week & & & \\
Consumption of fats and oils & & Reference category \\
$\quad$ Never & 1.097 & $2.99(1.63-5.53)$ & $<0.001$ \\
1-6 days a week & 2.002 & $7.40(3.89-14.05)$ & $<0.001$ \\
7 days a week & &
\end{tabular}

children could possibly due to lack of variety in the foods consumed and an overall inadequate food intake.

\section{Conclusion}

The findings of the present study revealed the high prevalence of cobalamin and folate deficiencies amongst children under 5 years of age and belonging to low income group in India. In view of the role of cobalamin and folate deficiencies in anemia, there is a need to have more scientific evidence on the prevalence of cobalamin and folate deficiencies in different regions of India so that public health intervention can be initiated at the national level. 


\section{REFERENCES}

1. International Institute for Population Sciences (IIPS) and ORC Macro National Family Health Survey (NFHS 3) 2005-2006. Mumbai IIPS. New Delhi: Ajanta Offset and Packagings Limited; 2006. p. 260-90.

2. De Benoist B. Conclusions of WHO Technical Consultation on folate and vitamin B12 deficiencies. Food Nutr Bull 2008;29 Suppl 2: :S238-44.

3. McNeely MD. Folic acid assay. In: Kaplan LA, Pesce AJ, editors. Clinical Chemistry. St. Louis: CV Mosby; 1984. p. 1402-6.

4. Chanarin I. The assay and concentration of folate in blood and other tissues: The Megaloblastic Anemias. Oxford; London: Blackwell Scientific Publications; 1969. p. 306-36.
5. Raven JL, Robson MB, Morgan JO, Hoffbrand AV. Comparison of three methods for measuring vitamin B 12 in serum: Radioisotopic, euglena gracilis and Lactobacillus $\mathrm{Br} \mathrm{J}$ Haematol 1972;22:21-31.

6. Taneja S, Bhandari N, Strand TA, Sommerfelt H, Refsum H, Ueland PM, et al. Cobalamin and folate status in infants and young children in a low-to-middle income community in India. Am J Clin Nutr 2007;86:1302-9.

7. Gomber S, Kumar S, Rusia U, Gupta P, Agarwal KN, Sharma S. Prevalence and etiology of nutritional anaemia in early childhood in an urban slum. Indian J Med Res 1998;107:269-73.

8. Dallman PR, Siimes MA. Percentile curves for hemoglobin and red cell volume in infancy and childhood. J Peadiatr 1979;94:26-31. 